\title{
Plastrum testudinis induces $\gamma$-globin gene expression through epigenetic histone modifications within the $\gamma$-globin gene promoter via activation of the p38 MAPK signaling pathway
}

\author{
XINHUA QIAN $^{1}$, JIA CHEN $^{1}$, DANHUA ZHAO $^{1}$, LISHAN GUO $^{1}$ and XINLAI QIAN ${ }^{2}$ \\ ${ }^{1}$ Department of Neonatology, Nanfang Hospital, Southern Medical University, Guangzhou, Guangdong 510515; \\ ${ }^{2}$ Pathological Staff Room, Xinxiang Medical University, Xinxiang, Henan 453003, P.R. China
}

Received February 4, 2013; Accepted March 15, 2013

DOI: $10.3892 /$ ijmm.2013.1338

\begin{abstract}
The pharmacologically-induced expression of the $\gamma$-globin gene, to increase fetal hemoglobin $(\mathrm{HbF})$ production, is a therapeutic strategy used for the treatment of $\beta$-thalassemia and sickle cell anemia (SCA). The aim of this study was to investigate the effects of Plastrum testudinis (PT) on differentiation, proliferation, $\gamma$-globin gene expression and $\mathrm{HbF}$ synthesis in human erythroid cells. For this purpose, we used the K562 human leukemia cell line and human erythroid progenitor cells from normal donors and patients with $\beta$-thalassemia cultured using the two-phase liquid culture system. The effects of PT on erythroid differentiation, proliferation, $\gamma$-globin gene expression and $\mathrm{HbF}$ synthesis, as well as the involvement of epigenetic histone modifications within the $\gamma$-globin gene promoter via activation of the $\mathrm{p} 38$ mitogen-activated protein kinase (MAPK) signaling pathway, were assessed by benzidine staining, trypan-blue dye exclusion, quantitative real-time RT-PCR (qRT-PCR), western blot analysis and chromatin immunoprecipitation (ChIP). PT promoted the erythroid differentiation of K562 cells, and increased $\gamma$-globin mRNA accumulation and $\mathrm{HbF}$ synthesis without inhibiting cell proliferation in K562 cells and human erythroid progenitors. PT exerted no effect on $\alpha$ - and $\beta$-globin gene expression. In human erythroid cells, PT activated the p38 MAPK signaling pathway, and enhanced the acetylation of histone $\mathrm{H} 3$ and $\mathrm{H} 4$, the phosphorylation of histone $\mathrm{H} 3$ within the $\mathrm{G} \gamma$ - and $\mathrm{A} \gamma$-globin gene promoter regions, $\gamma$-globin mRNA accumulation and $\mathrm{HbF}$ synthesis. These effects were suppressed by pre-treatment with the p38 MAPK inhibitor, SB203580. Epigenetic histone modifications within $\gamma$-globin gene promoter regions, via acti-
\end{abstract}

Correspondence to: Dr Xinhua Qian, Department of Neonatology, Nanfang Hospital, Southern Medical University, 1838 Guang Zhou Da Dao North, Guangzhou, Guangdong 510515, P.R. China E-mail: xinhua49@yahoo.com

Key words: plastrum testudinis, $\gamma$-globin gene, fetal hemoglobin, p38 mitogen-activated protein kinase, epigenetic modifications vation of the p38 MAPK signaling pathway, are important for the induction of $\gamma$-globin gene expression in human erythroid cells by PT. PT may be a novel potential therapeutic agent for $\beta$-hemoglobinopathies, including $\beta$-thalassemia and SCA.

\section{Introduction}

$\beta$-hemoglobin disorders, including $\beta$-thalassemia and sickle cell anemia (SCA), are the most prevalent monogenic inherited disorders that result from the deficient or altered synthesis of the $\beta$-globin chain of human hemoglobin (1). $\beta$-thalassemia is characterized by diminished or absent production of $\beta$-globin chains which causes a relative excess of $\alpha$-globin chains. The imbalance in the production of non- $\alpha / \alpha$-globin chains is the main factor responsible for the pathophysiology of $\beta$-thalassemia (2). In SCA, the substitution of glutamate for valine at position 6 of the $\beta$-globin chain leads to the synthesis of abnormal hemoglobin (HbS), which forms polymers that cause vascular occlusion under specific physiological conditions (3).

The only potential cures for these disorders are bone marrow transplantation, which is useful for only a minority of patients (4), and gene or cellular therapies, which have faced numerous challenges (5). Therefore, these treatments have significant limitations for widespread use, particularly in developing countries where affected patients are often unable to sustain the high costs of clinical management. In addition, a number of issues need to be resolved before gene therapy can be introduced into clinical trials, including the efficiency of transduction, transgene expression levels and safety concerns (6). The development of pharmacological therapeutics for $\beta$-hemoglobin disorders, including the possible use of fetal hemoglobin ( $\mathrm{HbF}$ ) inducers, is considered crucial (7). It has been known for some time that increasing $\mathrm{HbF}(\alpha 2 \gamma 2)$ expression is clinically beneficial for patients with $\beta$-thalassemia or SCA. The pharmacological reactivation of $\gamma$-globin gene expression, which is silenced in adults, can decrease the imbalance of non- $\alpha-\alpha$-globin chains in $\beta$-thalassemia, and elevating the $\mathrm{HbF}$ level can prevent $\mathrm{HbS}$ polymerization in SCA, substantially ameliorating the clinical symptoms of patients with these disorders (8). Therefore, a considerable research effort is underway to investigate the therapeutic approaches that involve the pharmacological induction of $\mathrm{HbF}$ expres- 
sion (9). This effort has led to the development of several agents, including 5-azacytidine, hydroxyurea, butyrate (and its analogues) and histone deacetylase (HDAC) inhibitors, as lead compounds capable of inducing $\gamma$-globin expression and increasing $\mathrm{HbF}$ levels (10-15). However, a number of factors limit the usefulness of these compounds. Butyrate and its analogues have short half-lives and may also cause hematopoietic suppression (16). Hydroxyurea, a drug commonly used for the treatment of SCA, induces a relatively weak expression of the $\gamma$-globin gene and is not effective in the majority of patients with $\beta$-thalassemia (17). When used long-term, 5-azacytidine and other DNA methyltransferase inhibitors may increase the risk of cancer, due to the non-specific modification of DNA (18). Therefore, there is an urgent need to identify novel agents that can induce $\mathrm{HbF}$ expression with higher efficiency and less toxicity.

The successful introduction of numerous compounds derived from traditional Chinese herbal remedies or the natural world have encouraged scientists to seek additional novel drugs from these ancient medicinal practices (19-22). In a previous study, we reported that serum obtained from Sprague-Dawley rats fed with Plastrum testudinis (PT) caused an increase in $\gamma$-globin gene expression and HbF production in K562 cells (23). PT (or turtle shell), which is the carapace and plastron of the turtle, is a well-known traditional Chinese medicine that has been used in China for over two thousand years, and has been documented in the oldest Materia Medica book, 'Shen Nong's Classic of Materia Medica'. According to the record in 'Shen Nong's Herbal Classic', PT is a valuable and top-grade Chinese medicine that has been used in clinical practice for the treatment of various types of anemia, bleeding disorders and bone diseases, as well as to nourish the body and enhance immunity $(24,25)$. Previous studies have demonstrated that PT promotes the proliferation and differentiation of mesenchymal stem cells (MSCs), protects the nervous system and exerts antioxidant activity (26-28). Although PT has been recorded as being used for the treatment of anemia, it is not clear whether PT could be used for the treatment of $\beta$-thalassemia and SCA, and its mechanisms of action are currently unknown.

The aim of this study was to determine whether PT can induce the erythroid differentiation of K562 cells and increase $\gamma$-globin gene expression and $\mathrm{HbF}$ synthesis in human erythroid cells, particularly those from patients with $\beta$-thalassemia, as well as to investigate its mechanisms of action. Our data demonstrate that PT is a novel therapeutic candidate for the treatment of $\beta$-thalassemia and SCA, which functions by activating the $\mathrm{HbF}$ gene through a mechanism involving epigenetic histone modifications within the $\gamma$-globin gene promoter via activation of the p38 mitogen-activated protein kinase (MAPK) signaling pathway.

\section{Materials and methods}

Reagents and antibodies. PT was purchased from Guangdong YiFang Pharmaceutical Co. (Guangdong, China); sodium butyrate (NaB) SB203580 (SB), benzidine, $\beta$-mercaptoethanol, human transferrin and phenylmethylsulfonyl fluoride (PMSF) were from Sigma (St. Louis, MO, USA); RPMI-1640 medium was obtained from Invitrogen (Carlsbad, CA, USA); TRIzol Reagent from Invitrogen Corporation (Grand Island, NY,
USA); L-glutamine was from Mediatech (Manassas, VA, USA); fetal bovine serum (FBS) was from Sijiqing (Hangzhou, China); Iscove's modified Dulbecco's medium (IMDM) was purchased from HyClone (Logan, UT, USA); cyclosporin A, recombinant human stem cell factor (rh-SCF) and recombinant human erythropoietin (rh-EPO) were obtained from ProSpec (Ness Ziona, Israel); 10\% conditioned medium was from the Chinese Academy of Sciences Cell Bank (Shanghai, China); dexamethasone was from Mechem (Chengdu, China); trypan blue was obtained from Gibco BRL (Grand Island, NY, USA); the real-time PCR kit and First Strand cDNA Synthesis kit were from GeneCopoeia (Rockville, MD, USA); sheep anti-HbF antibody was purchased from Abcam (Cambridge, MA, USA); anti-p38 MAPK antibody was from Cell Signaling Technology (Beverly, MA, USA); mouse anti- $\beta$-actin antibody was from Santa Cruz Biotechnology, Inc. (Santa Cruz, CA, USA); HRP-labeled rabbit anti-sheep $\operatorname{IgG}(\mathrm{H}+\mathrm{L})$ was from KPL (Gaithersburg, USA); HRP-labeled goat anti-mouse IgG $(\mathrm{H}+\mathrm{L})$ was from Zhongshan Golden Bridge Biotechnology (Beijing, China); the ECL Western Blotting Luminol Reagent kit was obtained from Merck (USA); the EZ-ChIP Chromatin Immunoprecipitation (ChIP) kit, anti-acetyl-histone $\mathrm{H} 3$ polyclonal antibody and anti-phosphoacetyl-histone $\mathrm{H} 3$ antibody were from Upstate Biotechnology (Lake Placid, NY, USA); and rabbit anti-tetra-acetyl-histone $\mathrm{H} 4$ polyclonal antibody was from Active Motif (Carlsbad, CA, USA). All other chemicals and reagents used were of analytical grade.

For drug induction experiments, $\mathrm{PT}$ or $\mathrm{NaB}$ were suspended as stock solutions in sterile $\mathrm{H}_{2} \mathrm{O}$, and diluted to the indicated concentrations in culture medium prior to experimentation. $\mathrm{NaB}$ was used at a concentration of $0.5 \mathrm{mmol} / \mathrm{l}$ as a positive control for the induction of $\mathrm{HbF}$ expression as previously described (29).

K562 cell culture. The human chronic myelogenous leukemia cell line, K562, was purchased from the Chinese Academy of Sciences Cell Bank (Shanghai, China). K562 cells were cultured in RPMI-1640 medium containing $2 \mathrm{mmol} / 1$ L-glutamine and supplemented with $10 \%(\mathrm{v} / \mathrm{v})$ heat-inactivated $\mathrm{FBS}, 100 \mathrm{U} / \mathrm{mL}$ penicillin and $100 \mu \mathrm{g} / \mathrm{ml}$ streptomycin, in a humidified $5 \% \mathrm{CO}_{2}$ atmosphere at $37^{\circ} \mathrm{C}$, as previously described (30). For the experiments, K562 cells were seeded in culture flasks at a density of $1 \times 10^{4}$ cells $/ \mathrm{ml}$. Cells were treated with 4 different concentrations of PT $(0.5,2.5,5$ or $10 \mathrm{mg} / \mathrm{ml})$ for various periods of time $(24,48,72,96,120$ or $144 \mathrm{~h})$, and the percentage of benzidine-positive cells was determined; $0.5 \mathrm{mmol} / \mathrm{l} \mathrm{NaB}$ acted as the positive control; the same volume of sterile $\mathrm{H}_{2} \mathrm{O}$ was used in the negative control experiments.

Culture of human erythroid progenitor cells. The experiments were approved by the Ethics Committee of Nangfan Hospital, Guangzhou, China (no. NFEC-201206-k2). Human erythroid progenitor cells were obtained from the umbilical cord blood from 8 healthy donors and the peripheral blood from 6 patients with $\beta$-thalassemia. All subjects provided written informed consent prior to enrollment in the study.

A two-phase liquid culture procedure was used to culture the human erythroid progenitor cells, as previously described (31-33). Briefly, mononuclear cells were isolated from cord blood or peripheral blood by centrifugation 
through a Ficoll-Hypaque density gradient (GE Healthcare, Uppsala, Sweden) prior to culture. Mononuclear cells were initially cultured in IMDM containing $10 \% \mathrm{FBS}, 1 \mu \mathrm{g} / \mathrm{ml}$ cyclosporin $\mathrm{A}$ and $10 \%$ conditioned medium, and grown in a humidified $5 \% \mathrm{CO}_{2}$ incubator at $37^{\circ} \mathrm{C}$. After 5-7 days in this phase 1 culture, non-adherent cells were harvested, washed and seeded at a density of $1 \times 10^{6} / \mathrm{ml}$ in IMDM containing $30 \% \mathrm{FBS}, 1 \% \mathrm{BSA}, 10 \mu \mathrm{mol} / 1 \beta$-mercaptoethanol, $1 \mu \mathrm{mol} / 1$ dexamethasone, $0.3 \mathrm{mg} / \mathrm{ml}$ human transferrin, $10 \mathrm{ng} / \mathrm{ml}$ rh-SCF and $1 \mathrm{U} / \mathrm{ml}$ rh-EPO; this corresponded to phase 2 of the culture. The resulting human progenitor cells were maintained at $37^{\circ} \mathrm{C}$ in a $5 \% \mathrm{CO}_{2}$ incubator for 14 days and, if indicated, the compounds were added on days 4 to 5 of phase 2 ; cell samples were analyzed on day 12 or 13 of phase 2 .

Benzidine staining. Erythroid differentiation of K562 cells was assessed using the benzidine $/ \mathrm{H}_{2} \mathrm{O}_{2}$ reaction to measure the proportion of benzidine-positive (heme-producing) cells, using a minor modification of a previously described technique (34). K562 cells were incubated with the indicated concentrations of PT or $\mathrm{NaB}$. Following treatment for the indicated periods of time, $0.5 \mathrm{ml}$ aliquots of cell suspension were removed, washed in PBS and added to $14 \mu \mathrm{l}$ benzidine reaction solution, which contained $0.4 \%$ benzidine, $12 \%$ acetic acid, $5 \%(\mathrm{w} / \mathrm{v})$ sodium nitroprusside and $1 \mu 130 \% \mathrm{H}_{2} \mathrm{O}_{2}$. The reaction was carried out in the dark at room temperature for $10 \mathrm{~min}$, after which 500 cells were counted under a microscope (TE2000-U, Nikon, Tokyo, Japan) and the percentage of benzidine-positive cells $(\mathrm{BZ} \%)$ was determined. The experiment was repeated 3 times.

Trypan blue dye exclusion assay. The proliferation of viable cells was determined by the trypan blue dye exclusion assay. $\mathrm{K} 562$ cells were grown with inducing agents ( $\mathrm{PT}$ or $\mathrm{NaB}$ ) at the indicated concentrations for periods of up to $144 \mathrm{~h}$ (for K562 cells). Human erythroid progenitor cells in phase 2 culture were cultured with inducing agents from day 6 to 14, and aliquots were removed daily or every 2 days to determine the number of viable cells. Cell viability was assessed by mixing aliquots of the cell suspensions with equal volumes of $0.5 \%$ trypan blue. Cells that accumulated the dye were considered dead. The cell inhibition rate was calculated as: cell inhibition rate $=1$ - cell viability rate $=[(\mathrm{Cn}-\mathrm{C} 0)-(\mathrm{Tn}-\mathrm{T} 0)] /(\mathrm{Cn}-\mathrm{C} 0)$ where $\mathrm{C}$ and $\mathrm{T}$ represent the number of cells per $\mathrm{ml}$ in the control and PT group, respectively, and $\mathrm{n}$ and 0 represent the day on which the count was made.

Quantitative real-time reverse-transcription polymerase chain reaction ( $q R T-P C R$ ). Analysis of globin gene expression was performed by qRT-PCR. Total RNA was isolated using TRIzol reagent, according to the manufacturer's instructions. RNA purity was determined using absorbance at 260 and $280 \mathrm{~nm}$ (A260/280). cDNA synthesis was performed using the First strand cDNA synthesis kit with oligo(dT) $)_{18}$ and M-MLV reverse transcriptase, according to the directions provided by the manufacturer. For qRT-PCR, the reaction mixture contained: 2X All-in-One q-PCR Mix, $10 \mu \mathrm{l}$; sample, $5 \mu \mathrm{l}$; forward primer $(4 \mu \mathrm{mol} / \mathrm{l}), 2 \mu \mathrm{l}$; reverse primer $(4 \mu \mathrm{mol} / \mathrm{l}), 2 \mu \mathrm{l}$; ROX Reference dye, $0.5 \mu \mathrm{l}$; nuclease-free water was added to a final volume of $20 \mu \mathrm{l}$. The reaction parameters used were:
Table I. Primer sequences and sizes of the real-time PCR products.

\begin{tabular}{|c|c|c|c|}
\hline Gene & Primer & Sequences $\left(5^{\prime} \rightarrow 3^{\prime}\right)$ & Size (bp) \\
\hline$\alpha$-globin & $\begin{array}{l}\text { Forward } \\
\text { Reverse }\end{array}$ & $\begin{array}{l}\text { tccccaccaccaagacctac } \\
\text { ccttaacctgggcagagcc }\end{array}$ & 256 \\
\hline$\beta$-globin & $\begin{array}{l}\text { Forward } \\
\text { Reverse }\end{array}$ & $\begin{array}{l}\text { ctcatggcaagaaagtgctcg } \\
\text { aattctttgccaaagtgatggg }\end{array}$ & 242 \\
\hline$\gamma$-globin & $\begin{array}{l}\text { Forward } \\
\text { Reverse }\end{array}$ & $\begin{array}{l}\text { ggcaacctgtcctctgcctc } \\
\text { gaaatggattgccaaaacgg }\end{array}$ & 250 \\
\hline GAPDH & $\begin{array}{l}\text { Forward } \\
\text { Reverse }\end{array}$ & $\begin{array}{l}\text { gcaccgtcaaggctgagaac } \\
\text { tggtgaagacgccagtgga }\end{array}$ & 221 \\
\hline $\mathrm{G} \gamma$-globin & $\begin{array}{l}\text { Forward } \\
\text { Reverse }\end{array}$ & $\begin{array}{l}\text { gctgcatgtggatcctgagaac } \\
\text { tctgcatcatgggcagtgag }\end{array}$ & 251 \\
\hline A $\gamma$-globin & $\begin{array}{l}\text { Forward } \\
\text { Reverse }\end{array}$ & $\begin{array}{l}\text { aagctttacacaggatcatgaagg } \\
\text { cagggtaggaagtattatggtgg }\end{array}$ & 249 \\
\hline Necdin & $\begin{array}{l}\text { Forward } \\
\text { Reverse }\end{array}$ & $\begin{array}{l}\text { gtcetctgectctgccatca } \\
\text { atacagggcactggecactc }\end{array}$ & 217 \\
\hline
\end{tabular}

$95^{\circ} \mathrm{C}$ for $10 \mathrm{~min} ; 95^{\circ} \mathrm{C}$ for $30 \mathrm{sec} ; 60^{\circ} \mathrm{C}$ for $30 \mathrm{sec}, 72^{\circ} \mathrm{C}$ for $1 \mathrm{~min}$; this was repeated for 40 cycles on an 8-tube ABI7500 PCR System (Applied Biosystems, Foster City, CA, USA). The housekeeping gene, human glyceraldehyde-3-phosphate dehydrogenase (GAPDH), was used for qRT-PCR normalization. The relative gene expression levels were expressed as the relative fold/percentage compared with the corresponding control, calculated using the $2^{-\Delta \Delta C t}$ method (35). The primers used were designed according to NCBI sequences using Prime 5.0 software, and were synthesized by GeneCopoeia. The primer sequences are presented in Table I.

Western blot analysis. K562 cells or human erythroid progenitor cells were lysed on ice for $20 \mathrm{~min}$ in $50 \mathrm{mmol} / \mathrm{l}$ Tris- $\mathrm{HCl}$ (pH 8), 150 mmol/1 NaCl, 2\% Nonidet P-40 (NP40), $0.5 \%$ sodium deoxycholate, $0.02 \%$ sodium azide and $0.1 \%$ SDS supplemented with $10 \mathrm{mmol} / \mathrm{l} \mathrm{PMSF}$. This was followed by centrifugation at $12,000 \mathrm{x}$ g for $15 \mathrm{~min}$ at $4^{\circ} \mathrm{C}$. The protein concentration was determined using a Bradford assay. For immunoblotting, $75 \mu \mathrm{g}$ of total cellular proteins per lane were separated by $15 \%$ SDS-PAGE, and then transferred onto polyvinylidene difluoride (PVDF) membranes (Millipore, Bedford, MA, USA). The membranes were subsequently blocked in $1 \mathrm{X}$ TBST (1X TBS/0.1\% Tween-20) containing $5 \%$ non-fat dry milk for $2 \mathrm{~h}$ at room temperature. Following a brief wash in 1X TBST, the membrane was incubated with primary antibodies (sheep anti-HbF antibody, anti-p38 MAPK antibody or mouse anti- $\beta$-actin antibody) for $1-2 \mathrm{~h}$ at room temperature, washed with $1 \mathrm{X}$ TBST, and then incubated with secondary antibodies [HRP-labeled rabbit anti-sheep IgG $(\mathrm{H}+\mathrm{L})$ or HRP-labeled goat anti-mouse IgG $(\mathrm{H}+\mathrm{L})]$ for $1-2 \mathrm{~h}$ at room temperature. $\beta$-actin was used as an endogenous control to normalize the differences in the amount of total protein in each sample. Proteins on the membrane were detected by the electrogenerated chemiluminescence method (ECL Western Blotting Luminol Reagent kit), according to the manufacturer's instructions. Band intensities were measured 
using Bandscan 5.0 software in the Bio-BEST-140E gel image system (SIM International, Newark, DE, USA).

ChIP assay. Following induction with $\mathrm{PT}$ or $\mathrm{NaB}$, aliquots of K562 cells or human erythroid progenitor cells were used for $\gamma$-globin quantifications and analysis of histone modification, carried out with a qRT-PCR-based ChIP assay (36). Briefly, protein-DNA crosslinking was achieved by incubating $1 \times 10^{7}$ cells in $1 \%$ formaldehyde for $10 \mathrm{~min}$ at $37^{\circ} \mathrm{C}$. After cell lysis, the lysate was sonicated to reduce DNA fragments to a size of 0.1 to $1.0 \mathrm{Kbp}$. DNA was co-immunoprecipitated in duplicate with histones using either a polyclonal antibody against diacetyl-histone $\mathrm{H} 3$, an antibody against tetra-acetylhistone $\mathrm{H} 4$ or an antibody against phosphoacetyl-histone $\mathrm{H} 3$. IgG was analyzed along with a negative control with no antibody. The immunoprecipitated DNA was purified by phenol/ chloroform extraction and dissolved in $50 \mu \mathrm{l}$ distilled water. In addition, $50 \mu 1$ aliquots of the sonicated lysate (total DNA) were directly subjected to DNA extraction without immunoprecipitation, and were dissolved in $100 \mu 1$ distilled water. Real-time PCR was used to determine the results. The primer sequences are presented in Table I.

Statistical analysis. All statistical analyses were conducted using SPSS software version 12.0 (SPSS Inc., Chicago, Il, USA). All experiments in this study were independently repeated at least 3 times. Data are presented as the means \pm SD. Statistical analysis was performed by one-way ANOVA, or repeated measures analysis of variance, where appropriate. The least significant difference post hoc test was used for ANOVA statistics. P-values $<0.05$ were considered to indicate statistically significant differences.

\section{Results}

$P T$ promotes erythroid differentiation and proliferation of K562 cells. To assess the effect of PT on the erythroid differentiation and proliferation of K562 cells, $5 \times 10^{4} / \mathrm{ml} \mathrm{K562} \mathrm{cells}$ were cultured in the absence or presence of PT at concentrations of $0.5,5$ and $10 \mathrm{mg} / \mathrm{l}$, or in the presence of $0.5 \mathrm{mmol} / 1$ $\mathrm{NaB}$ as the positive control, for periods of up to $144 \mathrm{~h}$. Every $24 \mathrm{~h}, 0.5 \mathrm{ml}$ of cell suspension was removed for benzidine staining to determine the proportion and the absolute number of benzidine-positive cells $/ \mathrm{ml}$ of culture. Fig. 1 illustrates the effects of PT on K562 cell differentiation and proliferation.

Fig. 1A presents microphotographs taken after 3 days of K562 cell culture, in the (a) absence or (b) presence of PT or (c) $\mathrm{NaB}$, indicating differentiated benzidine-positive cells. Fig. 1B and C illustrate the kinetic characteristics of K562 erythroid differentiation with various concentrations of PT, revealing that the induction of erythroid differentiation by PT was both time-and dose-dependent. Maximal stimulation of K562 erythroid differentiation was observed at a PT concentration of $5 \mathrm{mg} / 1$ after $96 \mathrm{~h}$ of culture: the proportion of benzidine-positive cells induced by PT (at $96 \mathrm{~h})$ was $11.72 \pm 0.68 \%$, similar to the maximal effect of $\mathrm{NaB}(10.99 \pm 0.79 \%$ at $72 \mathrm{~h})$. Of note, the absolute number of benzidine-positive cells induced by PT was $24084.3 \pm 3276.1$ (at $96 \mathrm{~h}$ ), a value significantly higher than that for obtained $\mathrm{NaB}(8242.0 \pm 423.0$, at $72 \mathrm{~h})$.
Fig. 1D and E illustrate the effect of PT on the proliferation of K562 cells. Fig. 1D presents representative results regarding cell growth. Fig. 1E shows that the inhibitory effects of PT on K562 cell proliferation were dose-dependent: after $96 \mathrm{~h}$ of culture, the inhibitory rates for $0.5,5$ and $10 \mathrm{mg} / \mathrm{l}$ PT were $3.9 \pm 0.23,22.47 \pm 0.70$ and $44.16 \pm 2.84 \%$, respectively. The inhibitory rate for PT was significantly lower than that for $0.5 \mathrm{mmol} / 1 \mathrm{NaB}(75.87 \pm 3.51 \%)$. At a concentration similar to that used therapeutically for the treatment of sickle cell disease $(0.5 \mathrm{mmol} / \mathrm{l}), \mathrm{NaB}$ caused a marked inhibition of cell proliferation.

These results suggest that a PT dose of $5 \mathrm{mg} / \mathrm{l}$ may be suitable for erythroid induction without affecting cell proliferation. In our opinion, it is very important that the induction of differentiation is not associated with the inhibition of cell growth. For this reason, PT has a significant advantage over other known inducers, such as 5-azacytidine, hydroxyurea and butyrate, which exert greater inhibitory effects on cell proliferation.

PT selectively induces $\gamma$-globin gene expression in human erythroid cells. In order to determine whether the induction of the erythroid differentiation of K562 cells by PT was associated with a selective upregulation of $\gamma$-globin gene expression, total RNA was extracted from the K562 cells that were either untreated, or treated with either PT $(5 \mathrm{mg} / \mathrm{ml})$ or $\mathrm{NaB}$ $(0.5 \mathrm{mmol} / \mathrm{l})$. Representative results from the qRT-PCR analysis are shown in Fig. 2A, and these indicate that the erythroid differentiation induced by PT after $96 \mathrm{~h}$ of treatment was associated with a sharp increase in $\gamma$-globin mRNA accumulation. Relative to the untreated cells, the maximal increases in $\gamma$-globin mRNA levels induced by PT and $\mathrm{NaB}$ were $8.17 \pm 1$.68fold $(96 \mathrm{~h})$ and $7.20 \pm 0.80$-fold $(72 \mathrm{~h})$, respectively $(\mathrm{P}<0.01)$. The $\mathrm{n}$-fold increase in $\gamma$-globin mRNA accumulation was measured using the GAPDH sequence as an internal control. Of note, no major increases in $\alpha$ - or $\beta$-globin mRNA accumulation were observed $(0.6 \pm 0.02$-fold, $\mathrm{P}<0.01$ and $0.96 \pm 0.02$-fold, $\mathrm{P}>0.05$, respectively) in the erythroid cells treated with PT, compared with the untreated cells. These data suggest that this compound merits further study for its possible effects on the expression of the $\gamma$-globin gene in erythroid cells isolated from patients with $\beta$-thalassemia.

To evaluate the selective effects of PT on $\gamma$-globin mRNA accumulation in human erythroid progenitor cells, we employed a two-phase liquid culture system as previously described (31-33). In phase 2 of this procedure (in the presence of EPO), the erythroid progenitor cells continue their proliferation and mature into $\mathrm{Hb}$-containing orthochromatic normoblasts. PT $(5 \mathrm{mg} / \mathrm{ml})$ or $\mathrm{NaB}(0.5 \mathrm{mmol} / \mathrm{l})$ were added on day 6 of phase 2. Cells were harvested on day 12 and total mRNA was isolated. The expression of globin genes in the erythroid progenitor cells from 6 patients with $\beta$-thalassemia were then analyzed by qRT-PCR using GAPDH mRNA expression as an internal control. The results shown in Fig. 2B indicate that PT caused a selective increase in $\gamma$-globin mRNA accumulation (mean, 4.94 \pm 1.17 -fold; range, 3.674- to 5.997-fold; $\mathrm{P}<0.05$ ), with no effect on the accumulation of $\alpha$-globin mRNA (mean, $0.72 \pm 0.06$-fold; range, 0.682 - to 0.787 -fold) or $\beta$-globin mRNA (mean, $0.97 \pm 0.28$-fold; range, 0.669 - to 1.23 -fold). The effects of $\mathrm{NaB}$ on $\gamma-\alpha$ - and $\beta$-globin genes were similar to those of 
A
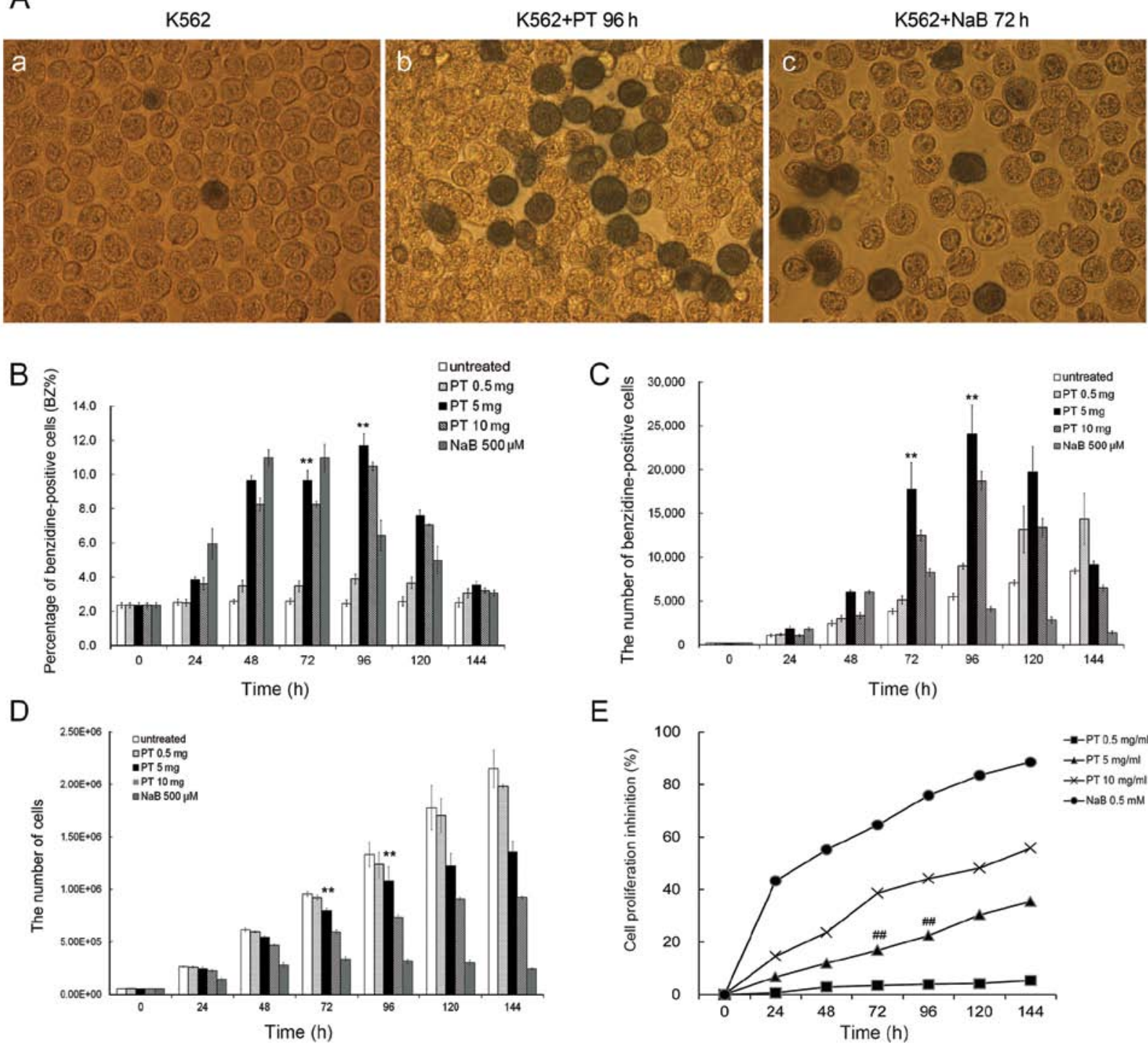

$E$

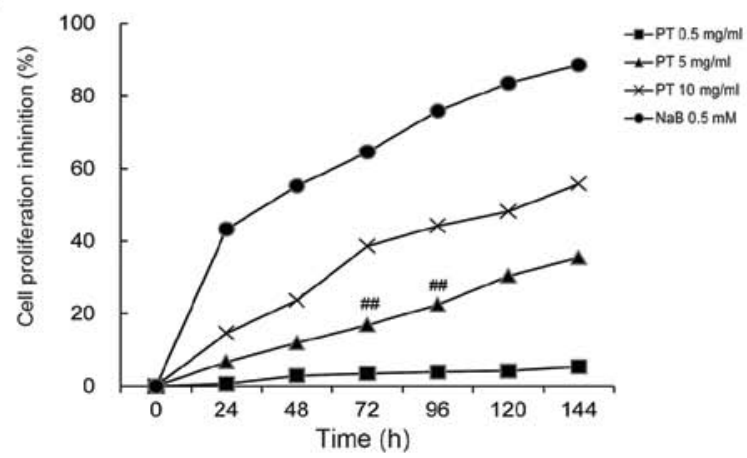

Figure 1. Effects of Plastrum testudinis (PT) on the erythroid differentiation and proliferation of K562 cells. (A) Microphotographs (magnification, $\mathrm{x} 400$ ) taken after K562 cell culture in the (a) absence or (b) presence of $5 \mathrm{mg} / \mathrm{ml} \mathrm{PT}$ for $96 \mathrm{~h}$ or (c) $0.5 \mathrm{mmol} / 1$ sodium butyrate (NaB) for $72 \mathrm{~h}$. The cells were stained with benzidine as described in Materials and methods. (B) Proportion of benzidine-positive (hemoglobin-containing) cells. (C) Absolute number of benzidinepositive cells. (D) Total number of cells per $\mathrm{ml}$ of culture. (E) Inhibitory rate on cell growth. Data represent the means \pm SD of 5 independent experiments. ${ }^{* *} \mathrm{P}<0.01$, vs. 0 h group; ${ }^{\# \#} \mathrm{P}<0.01$ vs. $\mathrm{NaB}$ group.

A

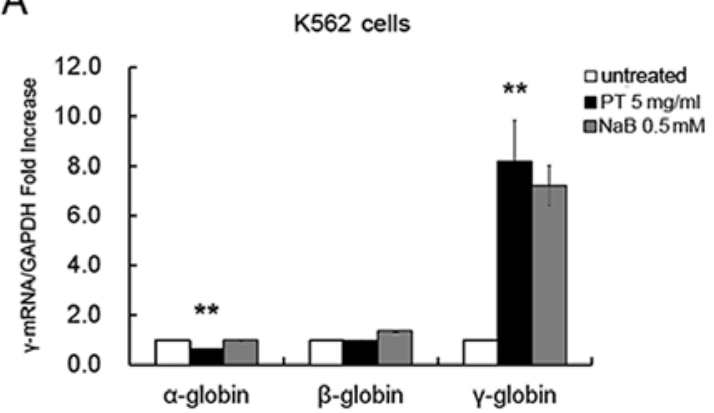

B

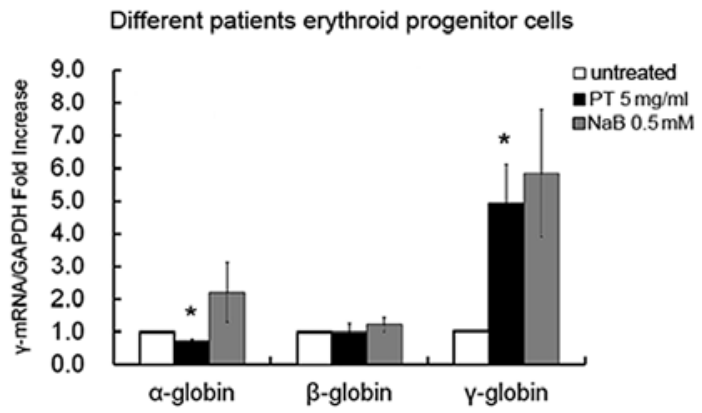

Figure 2. Effects of Plastrum testudinis (PT) on the expression of globin genes in K562 cells and human erythroid precursor cells, assayed by qRT-PCR. The expression levels of globin genes were normalized to the corresponding level of GAPDH. The expression levels of the globin genes in the negative control group were normalized to 1 , so that the values of each group are presented as the fold-increase relative to the negative control group. (A) Accumulation of $\alpha$-, $\beta$ - and $\gamma$-globin mRNA in K562 cells treated with $5 \mathrm{mg} / \mathrm{ml} \mathrm{PT}$ for $96 \mathrm{~h}$ or $0.5 \mathrm{mmol} / 1 \mathrm{NaB}$ for $72 \mathrm{~h}$. (B) The levels of $\alpha$-, $\beta$ - and $\gamma$-globin mRNA in erythroid precursor cells from 6 patients with $\beta$-thalassemia treated with $5 \mathrm{mg} / \mathrm{ml} \mathrm{PT}$ or $0.5 \mathrm{mmol} / 1 \mathrm{NaB}$. Data are presented as the means $\pm \mathrm{SD}$. ${ }^{*} \mathrm{P}<0.05$ and ${ }^{* *} \mathrm{P}<0.01$, vs. the negative control. 
A
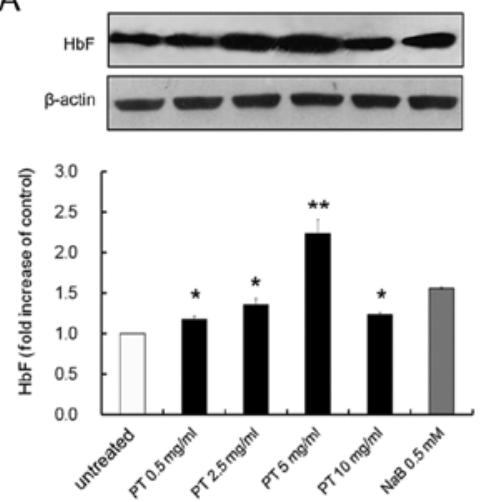

B
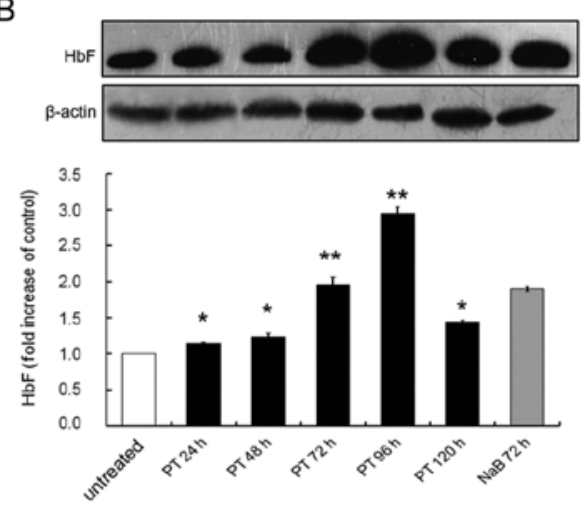

C
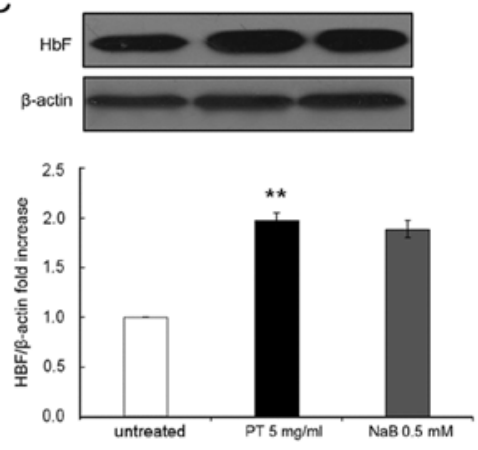

Figure 3. Effects of Plastrum testudinis (PT) on fetal hemoglobin (HbF) synthesis in K562 cells and human erythroid precursor cells, assayed by western blot analysis. The amount of $\mathrm{HbF}$ was normalized to the corresponding level of $\beta$-actin. The amount of HbF in the negative control group was normalized to 1 , so that the values of each group are presented as the fold-increase relative to the negative control group. Total proteins were isolated from K562 cells cultured in the absence or presence of the indicated concentrations of PT for $96 \mathrm{~h}$ or $0.5 \mathrm{mmol} / \mathrm{l} \mathrm{NaB}$ for $72 \mathrm{~h}(\mathrm{~A})$, or treated with $5 \mathrm{mg} / \mathrm{ml} \mathrm{PT}$ for the indicated periods of time or $0.5 \mathrm{mmol} / 1 \mathrm{NaB}$ for $72 \mathrm{~h}$ (B). The erythroid precursor cells from 6 patients with $\beta$-thalassemia, treated with $5 \mathrm{mg} / \mathrm{ml} \mathrm{PT}$ or $0.5 \mathrm{mmol} / 1 \mathrm{NaB}$ on day 6 of phase 2 of the two-phase liquid culture, were harvested following 6 days of treatment with drugs $(\mathrm{C})$. Results represent the means $\pm \mathrm{SD}$. ${ }^{*} \mathrm{P}<0.05$ and ${ }^{* *} \mathrm{P}<0.01$, vs. the negative control.

PT; however, a moderate inhibition of cell growth was observed in the PT-treated erythroid progenitor cells compared to those treated with $\mathrm{NaB}$.

PT enhances HbF synthesis in human erythroid cells. First, the effect of PT on HbF induction in K562 cells was examined. K562 cells were cultured for $96 \mathrm{~h}$ in the absence or presence of PT at $0.5,2.5,5$ or $10 \mathrm{mg} / \mathrm{l}$, and the levels of total protein were measured. The relative concentration of $\mathrm{HbF}$ was determined by western blot analysis, with $\beta$-actin used as an internal control for quantification. Representative results are shown in Fig. 3A, illustrating that treatment with PT increased $\mathrm{HbF}$ levels compared with the untreated control. The group data from 3 independent experiments revealed that PT significantly increased $\mathrm{HbF}$ levels in a concentrationdependent manner, from $1.17 \pm 0.04$-fold at $0.5 \mathrm{mg} / \mathrm{ml}$ to $2.23 \pm 0.17$-fold at $5 \mathrm{mg} / \mathrm{ml}$, compared with the untreated control. Thus, PT at $5 \mathrm{mg} / \mathrm{l}$ caused the optimal increase in $\mathrm{HbF}$ levels, similar to the observations made in the erythroid induction experiments (Fig. 1B and C). PT at $5 \mathrm{mg} / \mathrm{l}$ exerted a moderate inhibitory effect.

Second, the time dependence of the $\mathrm{HbF}$ induction in response to $5 \mathrm{mg} / \mathrm{l} \mathrm{PT}$ was investigated (Fig. 3B). The K562 cells were treated for $0,24,48,72,96$ or $120 \mathrm{~h}$, and the relative $\mathrm{HbF}$ levels were assessed by western blot analysis. As shown in Fig. $1 \mathrm{~B}$ and $\mathrm{C}$, the expression level of $\mathrm{HbF}$ increased until it peaked at $96 \mathrm{~h}$, and then slowly declined at $120 \mathrm{~h}$. The group data from 3 independent experiments (Fig. 3B) indicated that the HbF level significantly increased 2.95 \pm 0.09 -fold over the basal levels $(0 \mathrm{~h})$, and then gradually declined. These data also demonstrated that $0.5 \mathrm{mmol} / 1 \mathrm{NaB}$ was a powerful inducer of $\mathrm{HbF}$ expression: the optimal effect of $\mathrm{NaB}$ was a $1.90 \pm 0.03$-fold increase following $72 \mathrm{~h}$ of culture (Fig. 3B).

Third, we examined the effects of $\mathrm{PT}$ on $\mathrm{HbF}$ induction in cells derived from 6 patients with $\beta$-thalassemia. The HbF levels induced by PT in these patients increased 1.98 \pm 0.11 -fold (ranging from $1.97 \pm 0.15$ to $2.04 \pm 0.09$ ) compared with the untreated controls $(\mathrm{P}<0.01)$, and this change was significantly higher compared to the $1.62 \pm 0.23$-fold increase induced by $\mathrm{NaB}(\mathrm{P}<0.01)$ (Fig. 3C).

PT activates p38 MAPK signaling. In this series of experiments, we determined whether PT can activate the p38 MAPK pathway. The levels of phosphorylated p38 MAPK (p-p38) induced by PT were evaluated by western blot analysis (37). K562 cells treated with PT at various concentrations $(0.5,2.5$, 5 or $10 \mathrm{mg} / \mathrm{ml}$ ) displayed a steady increase in p-p38 expression, as shown in Fig. 4A. The increase in p38 MAPK phosphorylation by PT occurred in a dose-dependent manner, with the levels of induced p-p38 ranging from $1.14 \pm 0.15$-fold $(0.5 \mathrm{mg} / \mathrm{ml}$ $\mathrm{PT})$ to $5.02 \pm 0.52$-fold $(5 \mathrm{mg} / \mathrm{ml} \mathrm{PT})(\mathrm{P}<0.05)$. Time-course studies were then performed using the K562 cells treated with $5 \mathrm{mg} / \mathrm{ml} \mathrm{PT}$ for 6 to $96 \mathrm{~h}$ (Fig. 4B). The levels of p-p38 were normalized to those of total p38 (t-p38). As shown in Fig. 4B, we observed a 1.28 \pm 0.15 -fold induction of $\mathrm{p}$-p38 expression at $6 \mathrm{~h}(\mathrm{P}>0.05)$, a $1.7 \pm 0.22$-fold increase at $12 \mathrm{~h}(\mathrm{P}<0.01)$, a $6.52 \pm 0.47$-fold increase at $72 \mathrm{~h}(\mathrm{P}<0.01)$, and then a decline to $4.62 \pm 0.36$-fold at $96 \mathrm{~h}(\mathrm{P}<0.01)$. In addition, SB203580 (SB), a p38 inhibitor, was analyzed for its ability to block PT-activated p-p38 in K562 cells. As shown in Fig. 4C, in the absence of SB, PT caused a 5.10 \pm 0.35 -fold increase in p-p38 levels $(\mathrm{P}<0.05)$, consistent with our previous data. By contrast, pre-treatment with $10 \mu \mathrm{mol} / 1 \mathrm{SB}$ for $1 \mathrm{~h}$ significantly reduced the effect of the PT-mediated p-p38 induction (a 2.17 \pm 0.05 -fold increase of p-p38, corresponding to an inhibitory effect of $57.27 \%$; $\mathrm{P}<0.01$ ). As a positive control, the effects of SB were also determined on the effects of $\mathrm{NaB}$, a known p38 activator. Pre-treatment with $10 \mu \mathrm{mol} / 1 \mathrm{SB}$ inhibited NaB-mediated p-p38 induction by 71.38\% (NaB-induced changes in p-p38 levels of 5.12 \pm 0.15 -fold in the absence of SB and 1.46 \pm 0.03 -fold in its presence; $\mathrm{P}<0.01$ ). These data provide evidence that PT activates the p38 MAPK signaling pathway.

In the following set of experiments, the correlation between PT-induced p38 MAPK phosphorylation and PT-induced 
A

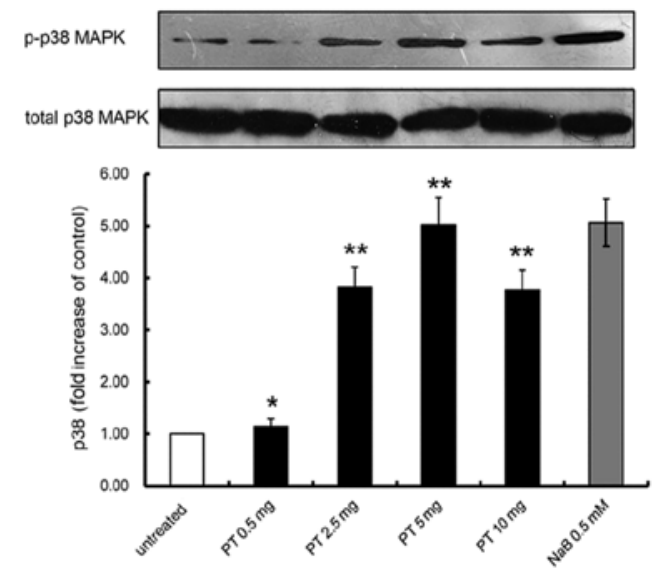

B
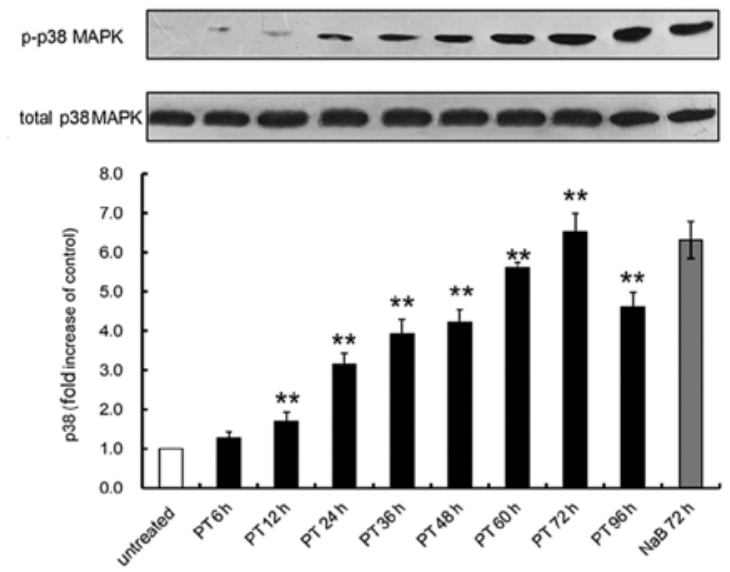

C

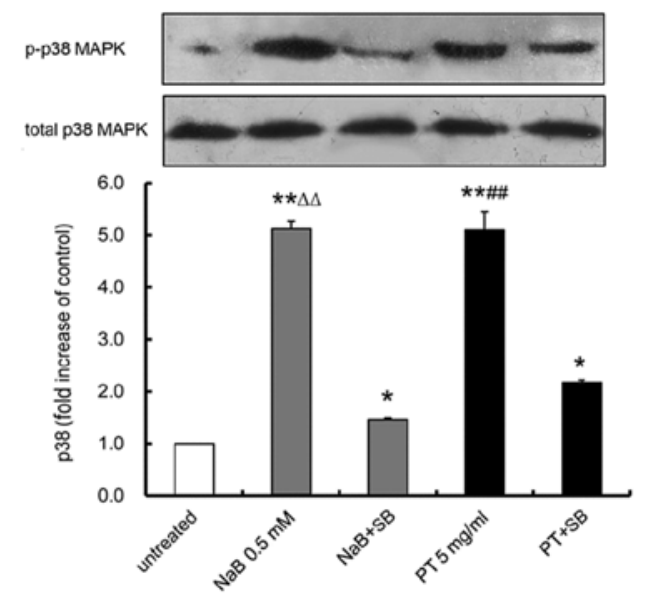

D

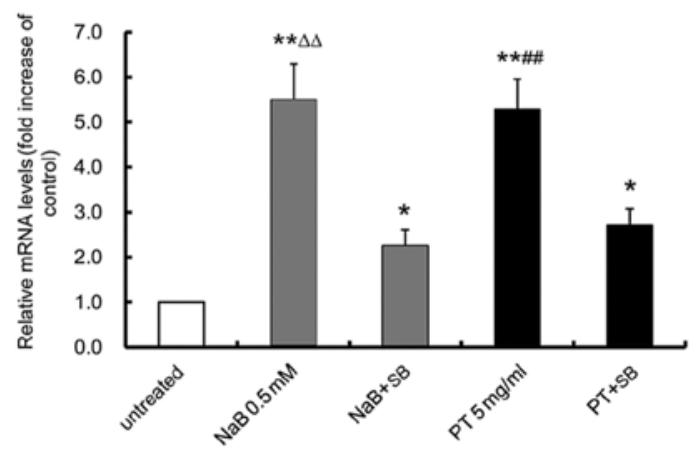

E

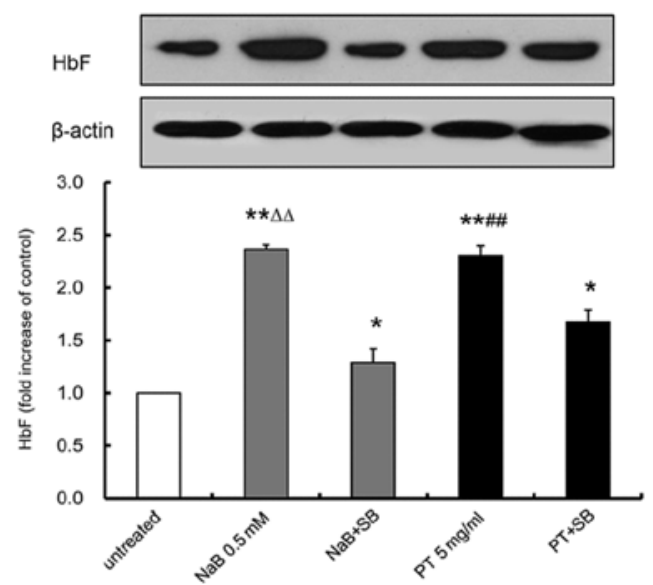

Figure 4. Effects of Plastrum testudinis (PT) on $\gamma$-globin gene expression and fetal hemoglobin $(\mathrm{HbF})$ synthesis via the activation of the $\mathrm{p} 38$ MAPK pathway, analyzed by western blot analysis and qRT-PCR. Total proteins were isolated from K562 cells treated with the indicated concentrations of PT or $\mathrm{NaB}$ for the indicated periods of time, to determine (A) the dose-dependence (B) and timecourse of p38 MAPK activation. (C) The experiment was performed in the absence or presence of SB203580 (SB). Levels of phosphorylated p38 (p-p38) were normalized to the total p38 (t-p38). The untreated K562 cell p-p38 levels were normalized to 1 , so that the values of each group are presented as the fold-increase relative to the negative control group. (D) p38 MAPK is required for $\gamma$-globin induction by PT. The qRT-PCR assay was performed in K562 cells treated with $\mathrm{PT}$ or $\mathrm{NaB}$, alone or in combination with SB pre-treatment. (E) p38 MAPK is required for $\mathrm{HbF}$ synthesis induced by PT. Western blot analyses were performed in K562 cells treated with $\mathrm{PT}$ and $\mathrm{NaB}$, alone or in combination with SB pre-treatment. The amount of $\gamma$-globin mRNA and $\mathrm{HbF}$ synthesis was calculated as the ratio to GAPDH mRNA and $\beta$-actin protein, respectively. The amounts of $\gamma$-globin mRNA and $\mathrm{HbF}$ in the negative control group were normalized to 1 , so that the values of each group are presented as the fold-increase relative to the negative control group. The data represent the means \pm SD of 3 independent experiments. ${ }^{* *} \mathrm{P}<0.01$, vs. the negative control; ${ }^{\#} \mathrm{P}<0.05$ and ${ }^{\# "} \mathrm{P}<0.01, \mathrm{PT}$ group vs. the $\mathrm{PT}+\mathrm{SB}$ group; ${ }^{\Delta} \mathrm{P}<0.01$, the $\mathrm{NaB}$ group vs. the $\mathrm{NaB}+\mathrm{SB}$ group.

and 2.36 \pm 0.03 -fold, respectively $(\mathrm{P}<0.001)$. By contrast, following pre-treatment with $10 \mu \mathrm{mol} / 1 \mathrm{SB}$ for $1 \mathrm{~h}$, exposure to PT or NaB resulted in a 2.70 \pm 0.37 - and $2.26 \pm 0.36$-fold reduction in $\gamma$-globin gene expression, and a $1.67 \pm 0.11$ - and $1.29 \pm 0.13$-fold reduction in $\mathrm{HbF}$ production, respectively $(\mathrm{P}<0.001)$. These

increases in $\gamma$-globin gene expression and $\mathrm{HbF}$ production was further determined. The data presented in Fig. 4D and $\mathrm{E}$ illustrate that in the absence of SB, PT and $\mathrm{NaB}$ significantly increased $\gamma$-globin mRNA expression by $5.28 \pm 0.67-$ and $5.48 \pm 0.80$-fold, respectively, and $\mathrm{HbF}$ production by $2.31 \pm 0.09$ - 
A

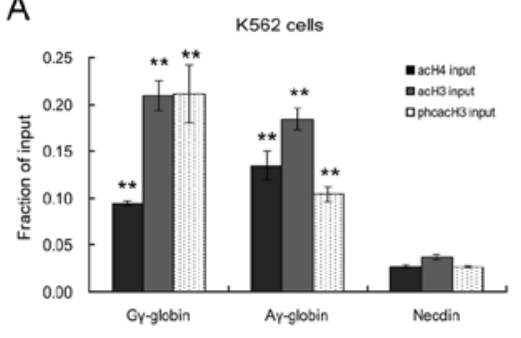

C

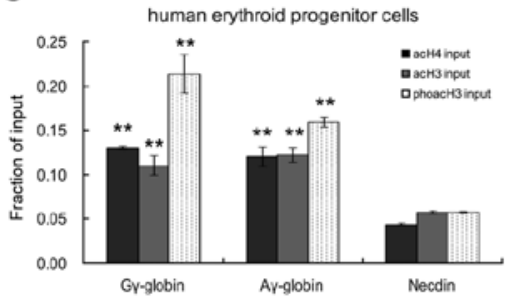

B

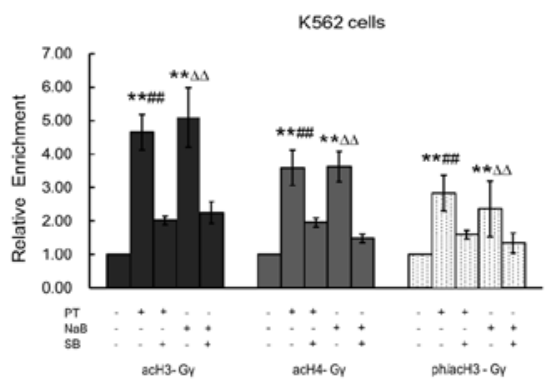

D

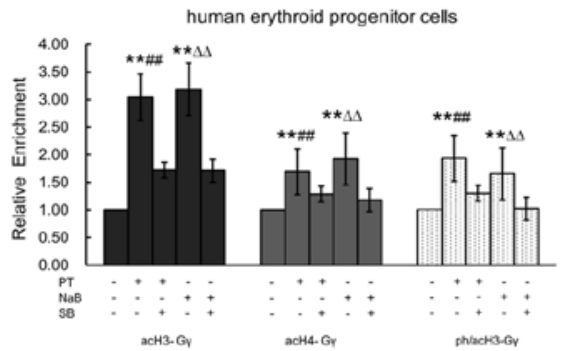

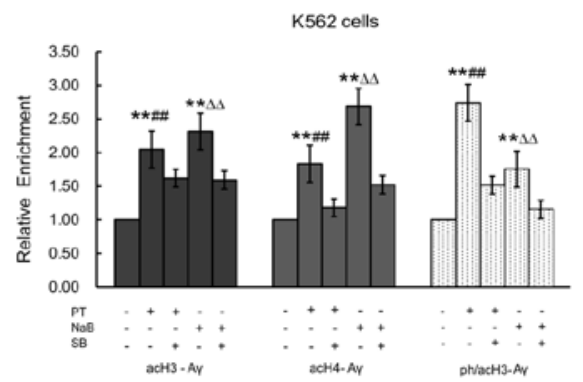

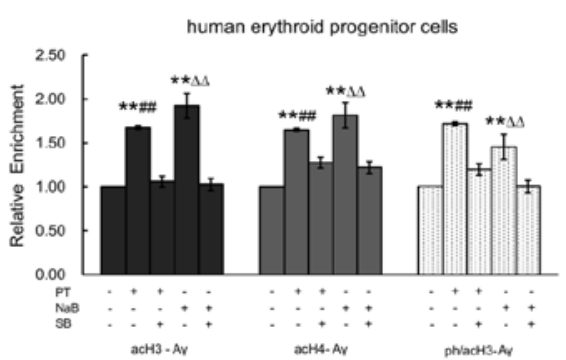

Figure 5. Effects of Plastrum testudinis (PT) on the expression and epigenetic histone modifications of $\gamma$-globin genes, assessed by qRT-PCR-based ChIP analysis. The levels of acetyl-histone $\mathrm{H} 3(\mathrm{acH} 3)$, acetyl-histone $\mathrm{H} 4(\mathrm{acH} 4)$ and phosphoryl-acetyl-histone $\mathrm{H} 3$ ( $\mathrm{ph} / \mathrm{acH} 3)$ within the promoters of the $\gamma$-globin and necdin genes in (A) K562 cells and (C) human erythroid precursor cells. The levels of acH3, acH4 and ph/acH3 within the promoters of the $\gamma$-globin genes in (B) K562 cells and (D) human erythroid precursor cells treated with PT or sodium butyrate (NaB), alone or in combination with SB203580 (SB) pre-treatment. Data are expressed as relative units. The means $\pm \mathrm{SD}$ of 3 experiments are shown. ${ }^{* *} \mathrm{P}<0.01$, vs. the negative control or necdin gene; ${ }^{\# \#} \mathrm{P}<0.01, \mathrm{PT}$ group vs. $\mathrm{PT}+$ $\mathrm{SB}$ group; ${ }^{\Delta} \mathrm{P}<0.01 \mathrm{NaB}$ group vs. $\mathrm{NaB}+\mathrm{SB}$ group.

results indicate that the p38 MAPK pathway contributes to the induction of $\gamma$-globin gene expression and the production $\mathrm{HbF}$ by PT.

$P T$ regulates epigenetic histone modifications within the $\gamma$-globin gene promoter regions through the p38 MAPK signaling pathway. To investigate whether the PT-induced $\gamma$-globin expression involves epigenetic histone modifications within the $\gamma$-globin gene promoter region via the p38 MAPK signaling pathway, we used a qRT-PCR-based ChIP assay as previously described $(38,39)$. The acetylation levels of histone $\mathrm{H} 3$ (acH3) and H4 (acH4), and the acetylation and phosphorylation levels of histone $\mathrm{H} 3$ ( $\mathrm{ph} / \mathrm{acH} 3)$, were determined within the $\mathrm{G} \gamma$ - and $A \gamma$-globin gene promoters and the necdin gene promoter (as a negative control) in human erythroid cells (K562 cells and erythroid progenitor cells from normal cord blood). We found high levels of acH3, acH4 and ph/acH3 within the promoters of the $\mathrm{G} \gamma$ - and $A \gamma$-globin genes in human erythroid cells, in which the $G \gamma$ - and $A \gamma$-globin genes are expressed. By contrast, there were low levels of acH3, acH4 and $\mathrm{ph} / \mathrm{acH} 3$ within the promoter of the necdin gene, which is not expressed in erythroid cells $(\mathrm{P}<0.05$; Fig. $5 \mathrm{~A}$ and $\mathrm{C})$.

In the K562 cells treated with PT or $\mathrm{NaB}$, the levels of acH3, acH4 and ph/acH3 within the $\mathrm{G} \gamma$ - and $\mathrm{A} \gamma$-globin gene promoters were significantly higher than those in the untreated cells (Fig. 5B). The increases in acH3, acH4 and ph/acH3 expression within the $\mathrm{G} \gamma$-globin gene promoter were 4.56-, 3.57- and 2.81-fold for PT, and 5.03-, 3.61- and 2.30-fold for $\mathrm{NaB}(\mathrm{P}<0.05)$, respectively. The increases in acH3, acH4 and $\mathrm{ph} / \mathrm{acH} 3$ expression within the $\mathrm{A} \gamma$-globin gene promoter were
2.04-, 1.81- and 2.74-fold for PT, and 2.31-, 2.67- and 1.75-fold for $\mathrm{NaB}(\mathrm{P}<0.05)$, respectively.

Similarly, the levels of acH3, acH4 and ph/acH3 within the $G \gamma$ - and $A \gamma$-globin gene promoters were also significantly higher in the erythroid progenitor cells from cord blood treated with PT or NaB compared to the untreated cells (Fig. 5D). The increases in acH3, acH4 and ph/acH3 expression within the $\mathrm{G} \gamma$-globin gene promoter were 3.02-, 1.68- and 1.91-fold for PT, and 3.18-, 1.92- and 1.72-fold for $\mathrm{NaB}(\mathrm{P}<0.05)$, respectively. The increases in acH3, acH4 and ph/acH3 expression within the A $\gamma$-globin gene promoter were 1.66-, 1.62- and 1.72-fold for PT, and 1.9-, 1.78- and 1.45-fold for NaB $(\mathrm{P}<0.05)$, respectively.

Of note, pre-treatment with $\mathrm{SB}$ reduced the effects of PT and $\mathrm{NaB}$ on acH3, acH4 and $\mathrm{ph} / \mathrm{acH} 3$ expression within the $\mathrm{G} \gamma$ - and $\mathrm{A} \gamma$-globin gene promoters, in the K562 cells and erythroid progenitor cells. As shown in Fig. 5B, the effects of PT on acH3, acH4 and ph/acH3 expression within the $\mathrm{G} \gamma$-globin gene promoter in the K562 cells were inhibited by $48.87,54.82$ and $57.23 \%$, respectively, while those of $\mathrm{NaB}$ were inhibited by $44.27,41.05$ and $57.43 \%$, respectively. For acH3, acH4 and ph/acH3 expression within the A $\gamma$-globin gene promoter, the inhibitory effects of SB were 79.10, 64.83 and $54.93 \%$ for PT, and $68.42,56.56$ and $65.78 \%$ for $\mathrm{NaB}$, respectively. In the erythroid progenitor cells (Fig. 5D), pretreatment with SB decreased the effects of PT on the levels of acH3, acH4 and ph/acH3 expression within the $\mathrm{G} \gamma$-globin gene promoter by $56.94,76.18$ and 67.67 , respectively, and the corresponding values for $\mathrm{NaB}$ were 53.62, 60.81 and $61.33 \%$, respectively. For the $\mathrm{A} \gamma$-globin gene promoter, the values were 
$63.28,77.43$ and $69.65 \%$ for PT, and $53.78,68.17$ and $62.74 \%$ for $\mathrm{NaB}$, respectively. These effects of SB were consistent with those on the transcriptional expression of $\gamma$-globin. Taken together, our results suggest that the p38 MAPK pathway plays an important role in the mechanism by which $\mathrm{PT}$ and $\mathrm{NaB}$ enhance the acetylation of histone $\mathrm{H} 3$ and $\mathrm{H} 4$, and the phosphorylation of histone $\mathrm{H} 3$.

\section{Discussion}

In this study, to our knowledge, we demonstrate for the first time that PT induces $\gamma$-globin mRNA accumulation and promotes $\mathrm{HbF}$ production in K562 cells and human erythroid progenitor cells from patients with $\beta$-thalassemia. First, we assessed the effects of PT on erythroid differentiation, cell proliferation, $\alpha$-, $\beta$ - and $\gamma$-globin gene expression and $\mathrm{HbF}$ synthesis in K562 cells. K562 cells represent a useful in vitro model which may be used to screen for novel drugs capable of inducing differentiation and to elucidate the molecular mechanisms that regulate the expression of human globin genes $(40,41)$. Our results demonstrated that PT significantly increased the number of benzidine-positive K562 cells, suggesting that PT induced the erythroid differentiation of these cells. Furthermore, this effect on erythroid differentiation was associated with an increase in $\gamma$-globin mRNA accumulation and $\mathrm{HbF}$ production. Of note, the optimal doses of PT which induced $\gamma$-globin expression, had no apparent cell growthinhibitory effect. By contrast, $\mathrm{NaB}$, which caused similar effects on differentiation, $\mathrm{HbF}$ synthesis and $\gamma$-globin mRNA accumulation, significantly inhibited K562 cell proliferation (Fig. 1). Another interesting result was that the effects of PT on $\gamma$-globin mRNA accumulation were clearly selective, since there were no detectable effects on the accumulation of $\alpha$ - and $\beta$-globin mRNA (Fig. 2). The selective effect of PT is crucial since it can decrease the imbalance of non- $\alpha$-/ $\alpha$-globin chains in $\beta$-thalassemia (2). Another significant aspect of this study is that we also evaluated the effects of PT on the induction of $\gamma$-globin mRNA expression and $\mathrm{HbF}$ production in human erythroid progenitor cells from patients with $\beta$-thalassemia, and found that PT was superior at inducing $\mathrm{HbF}$ expression compared to NaB. More importantly, we found that PT may be a safer drug since it had no apparent cytotoxic effects and caused a significantly lower inhibition of human erythroid progenitor cell proliferation compared with $\mathrm{NaB}$. Therefore, our study has identified a novel $\mathrm{HbF}$ inducer from a traditional Chinese medicine that shows great promise for the treatment of $\beta$-thalassemia and SCA.

However, the mechanism by which PT induces $\gamma$-globin gene expression is unknown. Research efforts to elucidate the mechanisms for reactivating $\gamma$-globin gene expression have been ongoing in order to aid the development of specific gene-based therapeutics for the treatment of hemoglobinopathies. Significant progress has been made over the past decade (42-45). In particular, evidence has emerged demonstrating an important role of cell signaling pathways, including cyclic guanosine monophosphate (cGMP), p38 MAPK, ROS and cytokine signaling pahtways, in mediating the effects of drug-induced $\gamma$-globin gene expression (7). Among these, the p38 MAPK signaling pathway has attracted particular attention since it has been demonstrated to play a role in the induction of $\gamma$-globin gene expression by various drugs $(37,46)$. MAPKs are key regulatory enzymes that transduce external signals into a complexity of intracellular responses. The direct activation of p38 MAPK in K562 stable lines with MAPK kinase kinase (MKK) 3 and MKK6, the immediate upstream activators of p38 MAPK, has been shown to increase $\gamma$-globin mRNA expression in the absence of $\mathrm{HbF}$ inducers (37). Of note, we found that the enforced p38 MAPK expression in K562 stable lines directly stimulated $\gamma$-globin gene expression and $\mathrm{HbF}$ production in the absence of inducers, suggesting a critical role for p38 MAPK in regulating $\gamma$-globin gene expression. In this study, we therefore first determined whether PT can activate the p38 MAPK signaling pathway. Our results demonstrated that PT enhanced p38 MAPK phosphorylation, and that this was accompanied by an increase in $\gamma$-globin mRNA expression and $\mathrm{HbF}$ production. However, pre-treatment with the $\mathrm{p} 38$ MAPK inhibitor, SB203580, abolished the effects of PT on p38 MAPK phosphorylation and $\gamma$-globin gene expression and HbF production (Fig. 4). This evidence supports the hypothesis that the p38 MAPK signaling pathway plays an important role in PT-induced $\gamma$-globin gene expression.

It is not known how the activation of the p38 MAPK signaling pathway results in $\gamma$-globin gene expression. During the past few years, evidence has accumulated that gene expression is controlled by alterations in chromatin structure produced by epigenetic modifications, including the methylation of DNA, and the acetylation, methylation, phosphorylation and ubiquitination of histones (47-49). The pattern of acetylation of histone $\mathrm{H} 3$ and $\mathrm{H} 4$ within the promoters of the $\alpha$-and $\beta$-globin genes has been characterized, and suggests that histone acetylation may play a pivotal role in the regulation of development-stage and tissue-specific expression of the genes of $\alpha$ - and $\beta$-globin clusters $(29,50,51)$. However, the correlation between $\gamma$-globin gene expression and histone phosphorylation within its promoter is not clear. It has been reported that the MAPK-mediated phosphoacetylation of histone $\mathrm{H} 3$ can induce gene regulation (52). In this study, we further investigated whether PT can induce not only the hyperacetylation but also the hyperphosphorylation of histones within the $\gamma$-globin gene promoter regions in human erythroid cells; we also examined the correlation between the p38 MAPK signaling pathway and histone modifications within the $\gamma$-globin gene promoter regions. The experimental approach of $\operatorname{ChIP}(38,39)$, used routinely to measure the levels and distribution of epigenetic markers, allows one to obtain molecular snapshots of a specific chromosomal region in living cells. Using ChIP, we provide evidence that PT induces the hyperacetylation of histone $\mathrm{H} 3$ and $\mathrm{H} 4$, as well as the hyperphosphorylation of histone $\mathrm{H} 3$ within the $\gamma$-globin gene promoter regions, and that this is accompanied by a significant increase in $\gamma$-globin gene expression and $\mathrm{HbF}$ synthesis. These results indicate that the PT-induced $\gamma$-globin expression involves histone modifications within the $\gamma$-globin gene promoter regions. Of note, the PT-induced $\gamma$-globin gene expression and histone modifications within its promoter regions were blocked by pre-treatment with the p38 MAPK inhibitor, SB203580, consistent with the hypothesis that the p38 MAPK signaling pathway plays an important role in the induction of $\gamma$-globin expression by PT through epigenetic histone modifications within the $\gamma$-globin gene promoter regions. 
In conclusion, we identified a novel effect of PT, a wellknown traditional Chinese medicine, to selectively induce $\gamma$-globin gene expression in human erythroid progenitor cells, suggesting that PT may have potential for development as a novel therapeutic agent for the treatment of $\beta$-thalassemia and SCA. To our knowledge, we are the first to clarify that the mechanism underlying the PT-induced $\gamma$-globin gene expression may involve the hyperacetylation of histone $\mathrm{H} 3$ and $\mathrm{H} 4$ and the hyperphosphorylation of histone $\mathrm{H} 3$ within the $\gamma$-globin gene promoter region, via activation of the p38 MAPK signaling pathway. Future studies are required to identify which components of PT are effective at inducing $\gamma$-globin gene expression, and in vivo studies are also warranted to further explore the benefits of PT.

\section{Acknowledgments}

This study was supported by a grant (no. 7005146) from the Natural Science Foundation of Guangdong Province and a special co-fund (no. 2011B032200002) from the Department of Science and Technology and Academy of Tradition Chinese Medicine of Guangdong Province, P.R. China.

\section{References}

1. Sankaran VG: Targeted therapeutic strategies for fetal hemoglobin induction. Hematology Am Soc Hematol Educ Program 2011: 459-465, 2011.

2. Higgs DR, Engel JD and Stamatoyannopoulos G: Thalassaemia. Lancet 379: 373-383, 2012.

3. Frenette PS and Atweh GF: Sickle cell disease: old discoveries, new concepts, and future promise. J Clin Invest 117: 850-858, 2007.

4. Lawson SE, Roberts IA, Amrolia P, Dokal I, Szydlo R and Darbyshire PJ: Bone marrow transplantation for beta-thalassaemia major: the UK experience in two paediatric centres. $\mathrm{Br}$ J Haematol 120: 289-295, 2003.

5. Sadelain M, Lisowski L, Samakoglu S, Rivella S, May C and Riviere I: Progress toward the genetic treatment of the betathalassemias. Ann N Y Acad Sci 1054: 78-91, 2005.

6. Sadelain M: Recent advances in globin gene transfer for the treatment of beta-thalassemia and sickle cell anemia. Curr Opin Hematol 13: 142-148, 2006.

7. Pace BS and Zein S: Understanding mechanisms of gammaglobin gene regulation to develop strategies for pharmacological fetal hemoglobin induction. Dev Dyn 235: 1727-1737, 2006.

8. Weatherall DJ and Clegg JB: The Thalassaemia Syndromes. 4th edition. Blackwell Science, Oxford, 2001.

9. Gambari R and Fibach E: Medicinal chemistry of fetal hemoglobin inducers for treatment of beta-thalassemia. Curr Med Chem 14: 199-212, 2007.

10. DeSimone J, Koshy M, Dorn L, et al: Maintenance of elevated fetal hemoglobin levels by decitabine during dose interval treatment of sickle cell anemia. Blood 99: 3905-3908, 2002.

11. Bradai M, Abad MT, Pissard S, Lamraoui F, Skopinski L and de Montalembert M: Hydroxyurea can eliminate transfusion requirements in children with severe beta-thalassemia. Blood 102: 1529-1530, 2003.

12. Mankidy R, Faller DV, Mabaera R, et al: Short-chain fatty acids induce gamma-globin gene expression by displacement of a HDAC3-NCoR repressor complex. Blood 108: 3179-3186, 2006.

13. Johnson J, Hunter R, McElveen R, Qian XH, Baliga BS and Pace BS: Fetal hemoglobin induction by the histone deacetylase inhibitor, scriptaid. Cell Mol Biol (Noisy-le-grand) 51: 229-238, 2005.

14. Witt O, Monkemeyer S, Ronndahl G, et al: Induction of fetal hemoglobin expression by the histone deacetylase inhibitor apicidin. Blood 101: 2001-2007, 2003.

15. Perrine SP, Castaneda SA, Boosalis MS, White GL, Jones BM and Bohacek R: Induction of fetal globin in beta-thalassemia: Cellular obstacles and molecular progress. Ann N Y Acad Sci 1054: 257-265, 2005.
16. Quek L and Thein SL: Molecular therapies in beta-thalassaemia. Br J Haematol 136: 353-365, 2007.

17. Fathallah H, Sutton M and Atweh GF: Pharmacological induction of fetal hemoglobin: Why haven't we been more successful in thalassemia? Ann N Y Acad Sci 1054: 228-237, 2005.

18. Saunthararajah Y, Lavelle D and DeSimone J: DNA hypomethylating agents and sickle cell disease. Br J Haematol 126: 629-636, 2004.

19. Normile D: Asian medicine. The new face of traditional Chinese medicine. Science 299: 188-190, 2003.

20. Bianchi N, Zuccato C, Lampronti I, Borgatti M and Gambari R: Fetal hemoglobin inducers from the natural world: A novel approach for identification of drugs for the treatment of \{beta\}thalassemia and sickle-cell anemia. Evid Based Complement Alternat Med 6: 141-151, 2009.

21. Fang $\mathrm{S}, \mathrm{Wu} \mathrm{Z}$, Zhang $\mathrm{X}$, et al: Clinical observation on YiSuiShengXueGranule on treating 156 patients with $\beta$-thalassemia major and the molecular mechanism study. Biol Pharm Bull 30: 2084-2087, 2007.

22. Yang M, Qian XH, Zhao DH and Fu SZ: Effects of Astragalus polysaccharide on the erythroid lineage and microarray analysis in K562 cells. J Ethnopharmacol 127: 242-250, 2010.

23. Guo ZM, Li HJ and Qian XH: $\gamma$-globin synthesis in K562 cells induced with Tortois plastron, Astragali, Salviae miltiorrhizae and Codonopsis pilosulae. J Exp Hematology 16: 520-524, 2008 (In Chinese).

24. Miao XY: Shennong Grass after Drainage (Shen Nong's Herbal Classic). China Press of Traditional Chinese Medicine, Beijing, 1997.

25. State Pharmacopoeia Commission of the People's Republic of China: Carapax et Plastrum Testudinis. In: Pharmacopoeia of The People's Republic China. Vol 1. pp15-16, 2000.

26. Chen DF, Zeng HP, Du SH, et al: Extracts from Plastrum testudinis promote proliferation of rat bone-marrow-derived mesenchymal stem cells. Cell Prolif 40: 196-212, 2007.

27. Xie XM, Li XC, Zhong YS, Huang CH and Chen DF: Study of antioxidant activities of Plastrum Testudinis in vitro. China Pharmacy 17: 1368-1370, 2006.

28. Chen DF, Li H and Du SH: Effects of plastrum testudinis on differentiation of transplanted mesenchymal stem cells into neurons in the injured spinal cord of rat. Chinese J of Neuroanatomy 22: 233-237, 2006.

29. Fathallah H, Weinberg RS, Galperin Y, Sutton M and Atweh GF: Role of epigenetic modifications in normal globin gene regulation and butyrate-mediated induction of fetal hemoglobin. Blood 110: 3391-3397, 2007.

30. Guo ZM, Li HJ and Qian XH: Accumulation of G $\gamma$-globin mRNA and induction of $\mathrm{HbF}$ in K562 cells induced by serum contained Huangqi. Pharm J Chin PLA 24: 15-19, 2008.

31. Fibach E, Manor D, Oppenheim A and Rachmilewitz EA: Proliferation and maturation of human erythroid progenitors in liquid culture. Blood 73: 100-103, 1989.

32. Fibach E: Cell culture and animal models to screen for promising fetal hemoglobin-stimulating compounds. Semin Hematol 38: 374-381, 2001

33. Wu QQ, Qian XH and Xu MJ: Effect of low-dose hydroxyurea with sodium butyrate on globin gene expression in human erythroid progenitor cells. Nan Fang Yi Ke Da Xue Xue Bao 29: 2073-2076, 2081, 2009 (In Chinese).

34. Lam LT, Ronchini C, Norton J, Capobianco AJ and Bresnick EH: Suppression of erythroid but not megakaryocytic differentiation of human K562 erythroleukemic cells by notch-1. J Biol Chem 275: 19676-19684, 2000.

35. Livak KJ and Schmittgen TD: Analysis of relative gene expression data using real-time quantitative PCR and the 2(-Delta Delta C(T)) Method. Methods 25: 402-408, 2001.

36. Im H, Grass JA, Johnson KD, Boyer ME, Wu J and Bresnick EH: Measurement of protein-DNA interactions in vivo by chromatin immunoprecipitation. Methods Mol Biol 284: 129-146, 2004.

37. Pace BS, Qian XH, Sangerman J, et al: p38 MAP kinase activation mediates gamma-globin gene induction in erythroid progenitors. Exp Hematol 31: 1089-1096, 2003.

38. Mukhopadhyay A,Deplancke B, Walhout AJ and Tissenbaum HA: Chromatin immunoprecipitation (ChIP) coupled to detection by quantitative real-time PCR to study transcription factor binding to DNA in Caenorhabditis elegans. Nat Protoc 3: 698-709, 2008.

39. Haring M, Offermann S, Danker T, Horst I, Peterhansel C and Stam M: Chromatin immunoprecipitation: optimization, quantitative analysis and data normalization. Plant Methods 3: 11, 2007. 
40. Rutherford TR, Clegg JB and Weatherall DJ: K562 human leukaemic cells synthesise embryonic haemoglobin in response to haemin. Nature 280: 164-165, 1979.

41. Bianchi N, Ongaro F, Chiarabelli C, et al: Induction of erythroid differentiation of human K562 cells by cisplatin analogs. Biochem Pharmacol 60: 31-40, 2000.

42. Mabaera R, West RJ, Conine SJ, et al: A cell stress signaling model of fetal hemoglobin induction: what doesn't kill red blood cells may make them stronger. Exp Hematol 36: 1057-1072, 2008.

43. Kiefer CM, Hou C, Little JA and Dean A: Epigenetics of betaglobin gene regulation. Mutat Res 647: 68-76, 2008.

44. Thein SL, Menzel S, Lathrop M and Garner C: Control of fetal hemoglobin: new insights emerging from genomics and clinical implications. Hum Mol Genet 18: R216-R223, 2009.

45. Bauer DE and Orkin SH: Update on fetal hemoglobin gene regulation in hemoglobinopathies. Curr Opin Pediatr 23: 1-8, 2011.
46. Witt O, Sand K and Pekrun A: Butyrate-induced erythroid differentiation of human K562 leukemia cells involves inhibition of ERK and activation of p38 MAP kinase pathways. Blood 95: 2391-2396, 2000.

47. Kouzarides T: Chromatin modifications and their function. Cell 128: 693-705, 2007.

48. Bernstein BE, Meissner A and Lander ES: The mammalian epigenome. Cell 128: 669-681, 2007.

49. Turner BM: Defining an epigenetic code. Nat Cell Biol 9: 2-6, 2007.

50. Wozniak RJ and Bresnick EH: Epigenetic control of complex loci during erythropoiesis. Curr Top Dev Biol 82: 55-83, 2008.

51. Fathallah H, Portnoy G and Atweh GF: Epigenetic analysis of the human alpha- and beta-globin gene clusters. Blood Cells Mol Dis 40: 166-173, 2008.

52. Clayton AL and Mahadevan LC: MAP kinase-mediated phosphoacetylation of histone $\mathrm{H} 3$ and inducible gene regulation. FEBS Lett 546: 51-58, 2003. 